\title{
University Students' Expectations and Perceptions of Study Abroad: Case Studies in Administrative Sciences
}

\author{
Claudia DÖRFER ${ }^{*}$ \\ Faculty of Public Accounting and Administration, Autonomous University of Nuevo León, Mexico \\ *Corresponding author: claudia.doerfer@uanl.edu.mx, cdoerfer@gmail.com
}

Received July 17, 2015; Revised July 25, 2015; Accepted July 31, 2015

\begin{abstract}
This study is part of a research project on student mobility in a Mexican public university in the northeast of the country and presents here the results from undergraduate students of public accounting, international business and information technology. The study shows the emotions that students experienced during and after their stay at a European university, influencing their cultural awareness, self-directed learning and personal development. The qualitative approach contextualizes the students' contributions, which were obtained through interviews and written reports. The work contributes to the rethinking of training processes, where curriculum support is included to promote intercultural competence in the preparation of students before going abroad.
\end{abstract}

Keywords: student mobility, intercultural competence, undergraduate

Cite This Article: Claudia DÖRFER, "University Students' Expectations and Perceptions of Study Abroad: Case Studies in Administrative Sciences.” American Journal of Educational Research, vol. 3, no. 8 (2015): 10361039. doi: 10.12691/education-3-8-14.

\section{Introduction}

Often the effectiveness of mobility programmes is measured by the number of outgoing students or the number of successfully completed projects. But who in the sending faculty actually questions the personal learning outcomes, the emotionally stressful situations and the personal enrichment achieved by going abroad? Are those emotions that allow or prevent self-directed learning in an intercultural context the same emotions that determine the success or otherwise of a stay abroad? An overview of the available literature shows that the most important effects of mobility programmes on people can be identified in the comprehensive development of the personality and language skills and intercultural sensitivity of the participants. From an individual perspective, the study abroad is an opportunity for learning, covering the development of the intercultural experience, sensitivity towards one's own and the other culture, language skills, vision of the world's diversity, and increase in reflection and cultural awareness; in addition, a greater appreciation of their own culture was detected $[3,4,7]$. The present work is part of a complex study lasting three years. Therefore it includes only the data related to undergraduate students in public accounting, international business and information technology and their experiences in European universities. This work is based on a brief conceptual review of literature on the importance of emotions for learning and tries to explore the relationship between emotions experienced with intercultural learning.

\section{The Study}

Participants in a mobility programme are located in a cultural space where their interactions and modes of communication are distant from their familiar environment and they tread uncharted territory. "Every step of my worldview is based on a given stock of past experience, both times my own immediate experiences and the experiences that are transmitted to me from my peers and especially my parents, teachers, and so on" [14]. Qualitative research using this approach is based on theoretical ideas, where the description of life in different parts of the world helps in understanding what is taken for granted culturally and forms strategies for action, recognizing structures and patterns of social reproduction [6].

\subsection{Concepts of Intercultural and Self-Directed Learning}

In M. J. Bennett's terms, intercultural learning is: "Acquiring increased awareness of subjective cultural context (world view), including one's own, and developing greater ability to interact sensitively and competently across cultural contexts as both an immediate and long-term effect of exchange" [2]. It is this consciousness that also allows self-directed learning. This concept has arisen in educational speeches since the 1970s, with very different definitions. For the purpose of defining the term, this study focuses on M. S. Knowles. The author proposes that self-directed learning is defined as "a process in which individuals take the initiative, 
with or without the help of others, in diagnosing their learning needs, formulating their learning goals, identifying human and material resources for learning, choosing and implementing appropriate learning strategies, and evaluating learning outcomes" [11]. The concept shows an emphasis on self-determination and self-control. It is based on the assumption that the learner determines the learning process target, time, place, content, methods and support. Both concepts require the awareness and motivation of the actors to perform in a particular cultural context. It is here, in a foreign context, where the student with an independent self-concept uses his acquired skills, and where applicable strategies are learned autonomously. This requires that the participant in an exchange programme has self-confidence, self-assurance, self-respect and selfacceptance, positive self-esteem and an affective component, to deal with situations in unfamiliar areas. What moves or stops the human being are his motives and emotions. Those forces that move the person develop implicitly and not in the same way for everyone-they are dependent on the experiences within a stimulating and reinforcing environment. The stimulating experience exerts a positive influence on the willingness and ability to learn $[1,15]$.

The cognitive adjustments undertaken by participants in mobility programmes abroad are reported by $\mathrm{J}$. Mestenhauser [13]. The author lists 13 specific cognitive settings: ability to recognize differences; understanding of the differences between emic and etic thinking; ability to recognize a knowledge gap; capacity for intercultural communication; ability to recognize missing knowledge; comparative thinking ability; capacity for self-perception; ability to know how to compare the countries; possession of knowledge of other countries; possession of diagnostic skills; understanding of differences; ability to recognize trends in other cultures; and understanding of cognitive complexity and cognitive integration. Besides experiencing limitations in their own cognitive maps, it is seen that the educational system has not prepared the students for some of the things they face, and there are many things of which they are not aware. "The results are uncertainty and insecurity, which have cognitive and affective consequences, with respect to decision making and critical thinking" [13].

By exhibiting a defence mechanism, it is possible to protect the self-concept from unexplored stimuli to such an extent that the person is prevented from functioning in an unfamiliar culture. Therefore it is important to raise the person's awareness of these defence mechanisms in order to minimize inhibition and to advance learning and development [17].

\subsection{Emotions and Learning}

Different theories and concepts exist about emotions. Each has a particular viewpoint regarding the reflection of reality. Older theories distinguish primary emotions (fear, anger, joy, sadness, trust, disgust, anticipation, surprise) and secondary emotions that are considered as a mixture of primary emotions. A close relationship between emotion and cognition, as well as between motivation and behaviour, is also assumed. With reference to Holodynski and Friedlmeier [10], Siecke classified three groups of paradigms of emotions: structuralist, functionalist and contextual [16].

The functionalist paradigm is the dominant view today. However, this study focuses on the contextual paradigm, because the concept of social constructivism takes into account that emotions are not only specific personal experiences, but are rooted in culture. Each individual has to transform them into something personal and intrapsychic during the socialization process. Emotions and forms of regulation are built into interactions with other people. Such feelings may be subject to rules, which in turn are embedded in social norms and expectations $[9,16]$.

In a self-directed learning process, the presence of feelings subject to rules is also supported. Those rules take place in a certain culture of learning, characterized by norms, values, attitudes and behaviours of a group of people. The rules are involved in, for example, the implicit or explicit demonstrations, everyday wisdom, moral imperatives and requirements that influence the behaviour and emotional experience of the student. These rules may be present in materials and learning support as advice, as can be transmitted in an educational institution or a company [15].

Upon approaching another culture, one receives outside stimuli from the new culture, which means organizing them into a system of beliefs and values other than the known. This requires understanding and evaluation of foreign values, measured and evaluated in terms of a 'sheer scale' of the alien culture. It also requires an understanding of oneself and one's own personal story, recognizing one's own culture in terms of its social history in relation to beliefs, values and norms. This seems to be less likely to happen when in contact with a foreign culture, because it demands a very intense rational and emotional process [17].

\subsection{Focus and Objective}

The study uses a mixed approach with a predominantly qualitative part. The different realities lived abroad and the impact of their experiences on the academic and personal lives of students are documented. The study starts from the assumption that students are active participants in cultural, educational and social subsystems. The main questions are: What motivates students to study abroad? How can emotions affect learning abroad? Is there any indication of increased cultural awareness and cultural learning?

The participants are 23 undergraduate students from the School of Public Accounting and Administration in a Mexican public university in the northeast of the country on mobility programmes in France, Germany, Italy and Spain. The age of the participants is between 19 and 20 years. The project consists of three phases, in which experiences are reported before, during and after the exchange. A questionnaire with open questions in the different phases will be sent to the participants, and there will be a brief interview [5]. The information will be processed using content and discourse analysis. The project is limited to a case study because of a lack of various resources, and because the number of subjects is small and their training very specific. The viability of the information obtained can only be described on the basis of 
data collection and interpretation of experiences in relation to this group.

\section{Findings}

\subsection{Motivation to Study Abroad}

Participation in an exchange programme, certainly for many students, is the most dynamic part of their academic career, a glimpse into their professional future. As one student expressed: "This exchange is an opportunity to grow in all aspects; it helps to acquire knowledge, academically and culturally. Also today, the competition becomes more demanding, and we have to be prepared to take on challenges and develop in [the context of] an international experience" (A04).

Ambitious personal desires are also a motivating source for participation in these programmes. As another student said: “...[The programme helped to] expand my network of contacts around the world, and ... I had the opportunity to come to a school where more than $30 \%$ of the students were from 38 or more countries, which would give me a great opportunity to meet people from all continents of the earth and to benefit me ... personally and professionally" (F08).

Another student expressed their expectations for the exchange. In addition to experiencing another culture and lifestyle, the programme was about departing from an affluent daily life and experiencing true emancipation: “...also an important point is to become independent a bit ... being away from my family and the comfort that one usually has when you have it all, at least in a simple way as it is having a family...desire to travel, meet different cultures outside of Italian culture, share a bit of Mexican culture” (I017).

\subsection{Studying and Teaching-learning Techniques}

One student mentions: "I attend courses at the Master's level, so I inquired about it. Here the Master's level takes only one year and has less content than in Mexico, but despite having less content, the content is very rich in [terms of] teaching and teachers take the time to explain each of the aspects of each topic. In a month of school we have seen only three subjects ..., in Mexico [there would have been] about five topics or maybe more. Yet the emphasis on each topic is deeper, more personalized classes" (E01).

The extract shows a difference between academic levels in Spain and Mexico. For this student, it was not difficult partnering to study at a higher level.

Regarding the interaction between students, it is interesting to see the organization and cooperation undertaken to achieve a common goal. Another student has lived in France: "At school, all the work we did together. We made a final work area. I realized that here it was customary to have many team meetings for each job. In these, we agreed on everything related to people and work, from agreeing on an issue, to reviewing the final work instead of dividing all online. I felt very good working this way, because the teamwork ... is part of the experience of living and working with international students" (F015).
Asked about academic work and what they find complicated, a student answers as follows: "The matter that I find a bit more complicated is finance, since there is a lot of material, so I'll have to start getting ready with plenty of time for the final examination and also for the project. If I had to compare my academic work with that in Mexico, I think the pace in the German university is a little faster, but I really like it, since I'm in college with a very good academic level” (A04). In this case the student realizes that deeper study is needed to prepare in advance and that is something unknown to her, despite having a very good academic and linguistic level. Also another student tells of difficulty in the level of understanding: "There is a matter that personally makes me feel as if I had never studied a career; my forte is not finance, and this matter of investment banking, for me it was a headache...classes were based on the teacher talking and talking about issues [of which I] only truly understood $10 \%$ of the total. Still, I do not have a test, but I feel nervous as, to finish, the exam will be oral; I hope to be ready by then" (I016).

When pursuing a subject that requires more dedication than the student usually invests, the stress level increases and causes the symptoms mentioned above. In addition, the student faced an oral examination, something he has not experienced in his career at the university of origin. Such tests are not included in the course of his study. This shows the lack of preparation for an academic culture that is different-for example, that in Germany and Italy is different to that in Mexico.

\subsection{Self-evaluation and Lived Emotions}

This study intends to show the extent to which participants come to an assessment of their own capabilities and achievements and what they learned over time while outside their own country. In the descriptions, the students particularly point out that they had to take their lives into their own hands independently and responsibly, reaching a new level of emancipation as a person. This includes managing time and money, orienting themselves in terms of what they want to achieve in their life and what they have to do so in order to fulfil that ambition, and taking time to think ahead. The experience will increase their level of awareness for different times in their lives. Following are some excerpts from interviews.

"...[The experience has] given me time to think why I'm here, what I am, what I really want, but mostly [how] to get everything I want, especially after this great achievement. I made some sacrifices [to do] this exchange, like leaving my work, but in the end you think it's for the better, and there are perhaps no similar opportunities later in life. I also feel an increase in the sense of valuing what we have, whether [it is] much or little" (I016).

The same student says that the exchange marked him emotionally, and several students acknowledge the impact: "... one of my wishes was to become independent a little, at least ... emotionally, and clearly in this regard I feel a big change, an emotional growth that strikes me as truth; I find that in the few months I've been here this has been a great step, even just being alone for a time ... " (I016).

Another student comments on organization as an achievement: "I feel that in the time I've been in France, I 
learned to better organize my time and money and therefore I have become more responsible” (F015).

\subsection{Change in Cultural Awareness}

When faced with a different culture, there are moments where both cultures are impacted, which may in turn impact the emotions experienced in terms of personal development, helping a person to learn more about themselves. As one student expressed: "As to my way of seeing the world, that has itself changed a lot. I always thought I was very open to new things, but I've noticed [that this is not always the case]. Many things still surprise me ... small things, like diversity in the meaning of freedom. [It] is not the same for a Frenchman as for a Mexican or a Moroccan. Cultural diversity is something you have to learn "(F021).

Another student expresses a conscious change in study habits: "I can also say now that my way of studying has changed a bit because now I [work several] days in advance because I am aware of the great content coming in the examination. When back in Mexico, I used to do it the day before" (F020).

The same student acknowledges a change in their personal and environmental consciousness, realizing they have matured and become responsible for their own daily life: "As a person, I have noticed several changes. Apart from being responsible and punctual in school, also it became a daily habit when out and about doing my thing. Another thing is that I became more independent. This is thanks to having to do things on my own-paying rent, banking, cooking, cleaning, managing my time and money, washing, etc., a lot of things I was not used to doing and here I learned how. I have also become healthier since being here as you walk a long way to get to everything and it has become a habit-you realize that one [does not] need the car to do all your daily life and I like it because I felt affection for the city when walking around" (F020, [CD]).

\section{Conclusions}

The study points out some of the different realities lived abroad and how these experiences impact on the academic and personal lives of undergraduate students in administrative sciences. It is noted that students participating in exchange programmes developed cultural awareness, along with an increase in personal development. Participation in a mobility programme advances cognitive, self and intercultural learning.

The results extracted from the completed study can be structured under the following topics.

1) Personal factors, such as increasing personal autonomy and academic improvement; changes in selfconcept; increased tolerance; economic planning; capacity for coexistence; positive and negative aspects of the experience and increased levels of frustration if their own culturally conditioned ideas encounter other cultural realities.
There was also loneliness and moments of sadness, and new understanding of their own language and culture, like the realization of a dream enabling participants to support changes in the personal growth of their self-concept.

2) Educational factors, such as cognitive, self-directed and intercultural learning.

3) Academic factors, such as the duration of undergraduate studies being different from those of the country of origin, which can be frustrating for students if the intellectual demand exceeds the level of personal attainment.

4) Supporting factors, such as preparation in terms of intercultural aspects besides the linguistic, and training in cultural aspects, including the academic culture, among other tools to help develop intercultural competence.

\section{References}

[1] Arnold, R. (2005). Die emotionale Konstruktion der Wirklichkeit. PädagogischerKonstruktivismus, Teil III. GEW-Zeitung RLP, Sonderbeilage, S. IX-XII.

[2] Bennett, M. (2009). Defining, measuring, and facilitating intercultural learning: a conceptual introduction to the intercultural education double supplement. Retrieved from http://www.idrinstitute.org/allegati/IDRI_t_Pubblicazioni/7/FILE_ Documento.pdf.

[3] De Wit, Hans (2005), “América Latina y Europa ante el fenómeno de la internacionalización”. En: Ginés Mora, J.; Fernández Lamarra, N. (coords.), Educación superior, convergencia entre América Latina y Europa [Procesos de evaluación y acreditación de la calidad], Universidad Nacional de Tres de Febrero, Argentina.

[4] Didou Aupetit, S. (2010). Mitos, expectativas y realidades de la movilidad estudiantil. Meta Política, 14, 70-83.

[5] Egan, J. (2008). Email interview. In: Lisa M. Given (Ed.), The Sage Encyclopedia of Qualitative Research Methods (p. 245). Thousand Oaks, CA: SAGE Publications.

[6] Flick, U. (2000). Qualitative Forschung; Ein Handbuch. Verlag Rowohlts: Reinbek.

[7] Gacel-Ávila, J. (2012). Comprehensive internationalisation in Latin America. Higher Education Policy, 25, 493-510.

[8] Gadamer, H.-G. (2005). Verdad y Método, 1-2(11ª). Sígueme: Salamanca.

[9] Hochschild, A. R. (1990). Das gekaufte Herz: Zur Kommerzialisierung der Gefühle. Frankfurt: New York.

[10] Holodynski, M., \& Friedlmeier, W. (1999). Emotionale Entwicklung und Perspektiven ihrer Erforschung. In W. Friedlmeier, \& M. Holodynski (Hrsg.), Emotionale Entwicklung. Funktion, Regulation und soziokultureller Kontext von Emotionen (pp. 1-26). Berlin: Heidelberg.

[11] Knowles, M. (1975). Self-directed learning: A guide for learners and teachers. Chicago.

[12] Mayring, P. (2000). Qualitative Inhaltsanalyse. In U. Flick (Ed.), Qualitative Forschung (pp. 468-475). Verlag Rowohlts: Reinbek.

[13] Mestenhauser, J. A. (1998). Internationalization of higher education: A cognitive response to the challenge of the twentyfirst century. International Education Forum, 18(1-2), 1-8.

[14] Schütz, A., \& Luckmann, T. (2003). Strukturen der Lebenswelt. UVK VerlagsgesellschaftmbH: Konstanz.

[15] Siecke, B. (2007). Lernen und Emotionen. Zur didaktischen Relevanz von Emotionskonzepten im Kontext beruflicher Bildung. Bielefeld.

[16] Siecke, B. (2010). Emotionen, Emotionskonzepte und Denkmodelle: Welche Bedeutung haben sie für das selbstgesteuerte Lernen? En: CSPC e-Learning der Zürcher Fachhochschule, E-Dossier, 07, 31-35.

[17] Trejo, L. (2011). Crisis y Transición. Proceso de cambio en un grupo de estudiantes mexicanos en Europa. México: Universidad Autónoma de Nuevo León. 